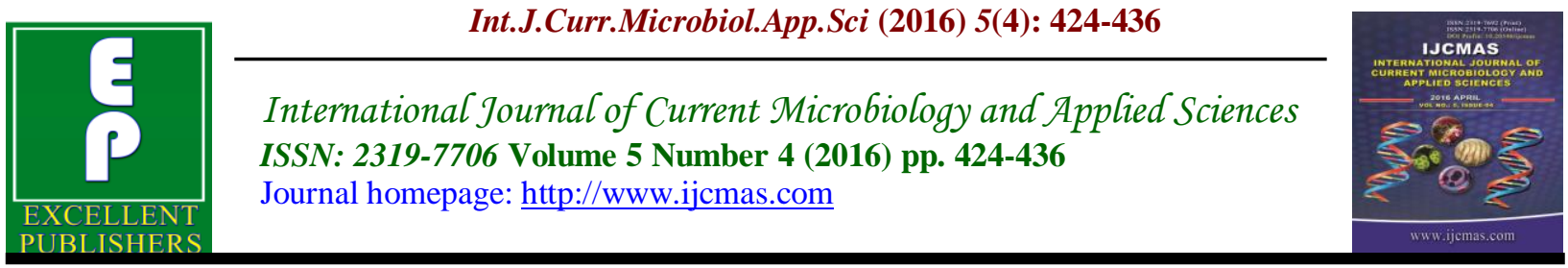

Review Article

http://dx.doi.org/10.20546/ijcmas.2016.504.050

\title{
Endophytes are Plant Helpers: An Overview
}

\author{
S. Rukshana Begum* and K.S. Tamilselvi \\ Department of Botany, PSGR Krishnammal college for women, Coimbatore- 641004, India \\ *Corresponding author
}

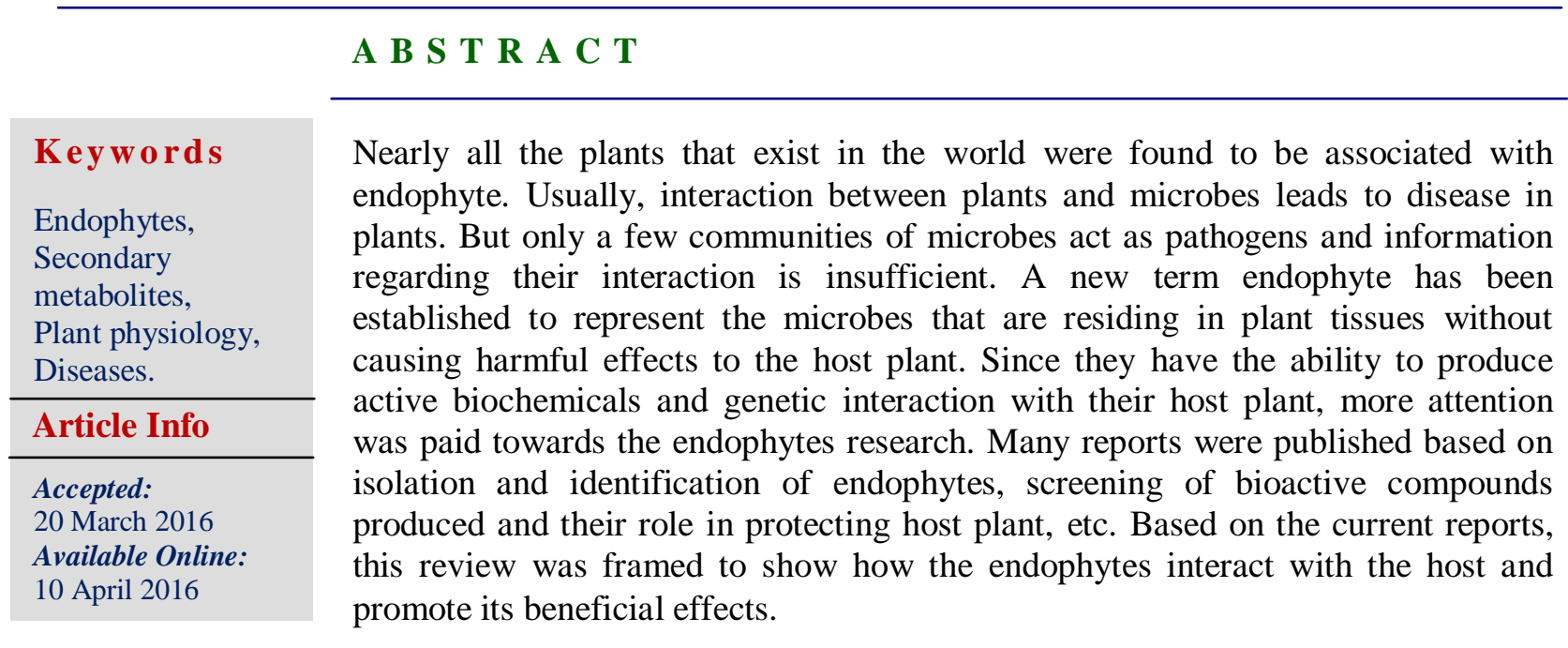

\section{Introduction}

In natural ecosystem plants are associated with endophytes. Endophytes are capable of producing extreme secondary metabolites that are used as biocontrol agents, immunosuppressive compounds, etc. (Tan and Zou, 2001). Endophytes have provided many useful compounds that are necessary in developing fields such as medicine, agriculture, biotechnology, etc. (Strobel et al., 2003). They may be seen in various habitats ranging from terrestrial to aquatic (Zhang et al., 2006). More importance is given to endophytes research because of declining global biodiversity, disappearance of species and ecosystem, etc. (Gimenez et al., 2007). Availability and composition of microbes present in the host plant depend on various factors.
Plant interaction with endophytes leads to plant productivity, enhance soil health, nutrients uptake by the plant (Mei and Flinn, 2010), and defence against plant stress, disease and insects (Gao et al., 2010).

Endophytes also play a major role in other important characteristics of plants, such as greater resistance to stress conditions (i.e., water), alteration in physiological properties, production of phytohormones and other compounds of biotechnological interest (i.e., enzymes and pharmaceutical drugs) (Azevedo et al., 2000). In addition to the economical aspects, the study of endophytic microorganisms has strong academic interests, concerning the discovery of new 
microbial species, mainly when tropical hosts are investigated (Azevedo et al., 2000). Researchers divide the activities of endophytes into direct and indirect methods. Direct method includes the influence of endophytes in plants under natural condition and indirect method refers to re-inoculation of isolated endophytes into the same or different host to enhance its particular character.

\section{Role of Endophytes in Plant Physiology}

Usually microbial symbionts were rarely considered for plant physiology studies (Arnold et al., 2007). For the past few years, studies on endophytes have increased because of their benefits provided to the host. Endophyte community structure (species diversity: richness and relative abundances) within the plant is dynamic and is influenced by biotic and abiotic factors such as plant species, microbe-microbe interactions, plant-microbe interactions, soil conditions and biogeography, both at local and larger scales (Gaiero et al., 2013).

\section{A Plant Growth Promoter}

Studies on interaction of endophytes with their host plants and their function within their hosts are important to deal with the biological significance of endophytes. The modulation of ethylene levels in plants by bacterially produced 1-aminocyclopropane1-carboxylate deaminase is a key feature that enables interference with the physiology of the host plant. Endophytes with this capacity might profit from association with the plant, because colonization is enhanced. In turn, host plants benefit by stress reduction and increased root growth. This mechanism leads to the concept of 'competent' endophytes, defined as endophytes that are equipped with genes important for maintenance of plant- endophyte associations (Hardoim et al., 2008).

Under natural conditions, endophytes promote plant growth by using various mechanisms. These include phosphate solubilization activity (Verma et al., 2001; Wakelin et al., 2004), indole acetic acid (IAA) production (Lee et al., 2004) and the production of a siderophore (Costa and Loper, 1994). Endophytic organisms can also supply essential vitamins to plants (Pirttila et al., 2004). Moreover, a number of other beneficial effects on plant growth have been attributed to endophytes and it includes osmotic adjustment, stomatal regulation, modification of root morphology, enhanced uptake of minerals and alteration of nitrogen accumulation and metabolism (Compant et al., 2005). The recent areas where these plant growth-promoting endophytes are being used in the developing areas of forest regeneration and phytoremediation of contaminated soils.

Associative bacteria as well as endophytic microbes use same mechanisms to influence plant growth. However, they differ in efficiency through which they exert their beneficial effect (Marella, 2014). The direct mechanisms are nitrogen $\left(\mathrm{N}_{2}\right)$ fixation, phosphate solubilization, insoluble iron chelation through the production of siderophores and phytohormones, such as auxins, cytokinins and gibberellins (GAs) (Tsavkelova et al., 2007; Jha et al., 2012). Sturz et al. (1998) provided the evidence for plant growth-promoting activity by endophytic bacteria. The experiments with potato and clover showed 21 isolates of endophytic bacteria are responsible for plant growth.

Mostly endophytic bacteria promote plant growth by nitrogen fixation. Diazotrophy is usually used to study the plant growth. 
Endophytic diazotrophs are assumed to have an advantage over root-associated diazotrophs, such as Azospirillum and Azotobacter, where they colonize the interior rather than the surface of the plants. Therefore, they exploit carbon substrates supplied by the plant. Moreover, they are located within the underground roots and dense plant tissues. The bacteria are likely to be growing within a low partial oxygen pressure environment, which is necessary for the expression and operation of nitrogenase (Baldani et al., 1997).

Some important diazotrophic bacteria, such as Acetobacter diazotrophicus, Herbaspirillum sps. and Azospirillium sps., isolated from some agricultural crops showed evidence that these bacteria actually fix nitrogen in their host plants. The researchers suggested that the plant growth promotion might have been caused by enhanced plant mineral uptake and improved plant-water relationship and production of some plant growth regulators. All the above methods may be considered to be causal agents for altering plant growth and development. But the correct mechanism behind this was still not yet clear.

Many endophytic bacteria and fungi isolated from plants were tested for the production of important growth hormones because the endophytes have the capacity to produce metabolites same as their host plant. Some important growth hormones are IAA (Shin et al., 2007; Sheng et al., 2008; Luo et al., 2012; Dalal and Kulkarni, 2013; Deshwal and Kumar, 2013; Jasim et al., 2013; Syamsia et al., 2015), GA (Hamayun et al., 2009, 2010; Khan et al., 2012), auxins and cytokinins (Dalal et al., 2013). Some important plant growth-promoting activities are listed in Table 1.
Bandara et al. (2006) studied the effects and potential of endophytic bacterial and fungal interactions in Oryza sativa and found two types of interactions, biofilms (bacteria attached to mycelia) and mixed cultures (no such attachments). The experiment was mainly conducted to test the IAA production by bacteria and fungi (mixed/separated) and by its interaction (biofilms). The results revealed that biofilms showed high productivity than the mixed cultures which is essential for plant growth. Endophytic bacteria enhance plant growth by producing plant growth regulators such as GAs, cytokinins and IAA, which directly or indirectly promote plant growth and development (Holland, 1997; Barka et al., 2002).

Various reports were produced based on in vitro experiments. Paecilomyces formosus (cucumber), Penicillium minioluteum (Glycine max L.), Phoma glomerata and Penicillium sp. (Waqas et al., 2012) were inoculated into GA-deficient mutant rice cultivar Waito-C and normal GA biosynthesis rice cultivar Dongjinbyeo. Culture filtrate of isolated strain showed maximum growth and increased GA production (Khan et al., 2011, 2012).

Euphorbia pekinensis, a medicinal plant, was inoculated in vitro with fungi isolated from the same plant and from other plant. Plant growth-promoting compounds were found to be higher in plants that were inoculated with fungus which were isolated from same plant (Dai et al., 2008). For instance, seed treatment of maize with a culture of Burkholderia cepacia, isolated from the rhizosphere of maize, resulted in disease suppression and growth promotion (Bevivino et al., 1998). 


\section{A Plant Protector}

The natural and biological control of pests and diseases affecting cultivated plants have gained much attention in the past decades as a way of reducing the use of chemical products in agriculture (Azevedo et al., 2000). The use of agrochemicals, though decreased the attack of insects and phytopathogenic microorganisms, still represents a high risk to field workers and consumers. Many endophyte communities were isolated from agricultural crops. Not all of the endophyte-plant associations make plants more resistant to pests or diseases (Gimenez et al., 2007). Endophytes are gaining attention as a subject for research and applications in plant pathology. This is because, in some cases, plants associated to endophytes have shown increased resistance to plant pathogens, particularly fungi and nematodes (Zabalgogeazcoa, 2008)

\section{Against Diseases}

Recently researchers focused on study of endophytes against some important diseases caused by several pathogens and insects. This includes some direct, indirect and ecological effects. Numerous plant-growth promoting endophytic strains have been isolated from the internal tissues of various crops and tested against effective diseases (Barka et al., 2002). Researchers used to handle the in vitro co-culture techniques or compare the survival rate of plant inoculated with/without endophytes. By using these techniques, several potential mechanisms were framed to show endophytes which have the capacity to limit the pathogen damage. When pathogens and the plant interact directly, endophytes suppress the pathogen by producing some antibiotics (lytic enzymes). Endophytes have the capacity to produce antibiotics that act as antifungal, antibacterial and insecticidal properties, which strongly inhibit the growth of other microorganisms, including plant pathogens (Gunatilaka, 2006). Endophytes which were isolated from various plants have the capacity to act against several pathogenic organisms such as Streptomyces sp. against Alternaria brassicicola (Igarashi et al., 2000), Cryptosporiopsis quercina against Candida albicans (Strobel et al., 1999), Nigrospora sp. against Fusarium oxysporum and Phytophthora spp. (Doley and Jha, 2010), Talaromyces flavus against the diseases produced by non-sesquiterpene peroxides (Talaperoxides AD (1-4)) (Li et al., 2011).

Endophytes indirectly affect the pathogens by providing more strength to its host plant through secondary metabolite. Bhowmik et al. (2002) and Fu et al. (1999) reported that cotton seed and tissues were inoculated with bacterial endophytes for reducing cotyledonary infection with Xanthomonas axonopodis pv. malvacearum (Smith) Vauterin (Xam) and for effective seed germination and better control of cotton wilt caused by Verticillium dahliae. Many tropical plants living in highly humid environments (rainforest) were not affected by Oomycetes. Their associated endophytes produced active metabolites against Phytophthora and Phytium (Strobel et al., 2003).

Burkholderia cepacia and $P$. aeruginosa isolated from symptomless oil palm root tissues showed potential to inhibit the spread of Ganoderm boninense (Basal stem rot disease). These two bacteria were reinoculated into oil palm seedlings which resulted in inhibition of $G$. boninense (Sapak et al., 2008). Theobroma cacao collected from lowlands of Panama was used for isolation of endophytic fungi. The isolated fungus were introduced into young seedlings of T. cacao and were found to inhibit leaf 
necrosis and leaf mortality caused by Phytophthora sp. The results revealed the intrinsic activity against the pathogen and explained the mechanism of horizontal transmission of endophytes (Arnold et al., 2003). The presence of compounds like IAA suggested a possible regulation of plant processes by endophyte metabolites (Gimenez et al., 2007).

\section{Against Insects}

The capacity of endophytic fungus to repel insects, induce weight loss, growth and development reduction and even to increase pest death rate was correlated with toxin production which act as protectors of host against different herbivores. Patterson et al. (1992) observed in Lolium and Festuca that the production of alkaloids by Acremonium reduced attacks of the Japanese beetle Popilla japonica. Members of Acremonium generally have the capacity to act against some insect pests. So they can be transferred to endophyte-free plant to resist against certain pests. Koga et al. (1997), by infecting Festuca arundinacea Shreb and Lolium perenne seeds with the endophytic fungus Acremonium, obtained plants resistant to the bluegrass webworm Parapediasia teterrella, Chaetomium and Phoma endophytes of wheat when inoculated were active against foliar diseases caused by Puccinia and Pyrenophora spp. (Dingle and McGee, 2003; Istifadah and McGee, 2006)

Bing and Lewis (1993) also reported that the entomopathogenic fungus Beauveria bassiana has been used for a long time in the control of the European corn borer and it was isolated as endophyte from corn. It has been discovered that grasses with high endophyte content were often resistant to attack by certain insects (Dutta et al., 2014). Phomopsis oblonga against Physocnemum brevilinenu beetle (Webber, 1981),
Muscodor vitigenus against heat stem sawfly (Daisy et al., 2002). Harley and Smith (1983) found that many orchids contain endophytic fungi of genus Rhizoctonia. Orchid seeds are small and lack sufficient nutrient for embryo development. The endophytic fungi grow out of the seeds after dispersal and enzymetically degrade the bark or other substrate to supply nutrient for developing orchid embryo (Dutta et al., 2014).

\section{Against Nematodes}

In some cases, the compounds responsible for the nematicidal activity observed in some plants was due to the production of 3hydroxypropionic acid by the endophytes Phomopsis phaseoli and Melanconium betulinum Schumach \& Kunze. However, other authors attributed these effects to 3nitropropionic acid (3-NPA) (Gimenez et al., 2007). Endophytic colonization of $F$. oxysporum showed resistance towards pests and diseases. Under in vitro condition $F$. oxysporum was tested against Pratylenchus goodeyi and Helicotylenchus multicinctus, plant-parasitic nematodes on banana (Waweru et al., 2014). Bacterial endophytes like Bacillus spp., Pseudomonads, Arthrobacter spp., Micrococcus spp., Curtobacterium sp., Serratia isolated from Piper nigrum L. was used for in vitro bioassay against the nematode Meloidogyne incognita (Aravind et al., 2009). Endophytes which act against some nematodes were listed in Table 2.

\section{An Nutrient Enhancer}

Some endophytes appear to possess the ability to manipulate host plant metabolism to increase nutrient uptake and change nutrient homeostasis. Neotyphodium coenophialum, an endophytic fungus, was isolated from $F$. arundinacea. Under in vitro condition, two cloned tall fescue plants were 
developed with and without the isolated strain in response to phosphorous deficiency. Relative growth of shoot and root, concentrations of potassium, iron and copper were found to be high in infected plants in response to phosphorous (Malinowski et al., 2000); likewise when Bacillus sp. was inoculated to sweet sorghum, the uptake of heavy metals like cadmium and magnesium was increased in infected plants (Luo et al., 2012).

\section{A Stress Controller}

One of the effective ways of developing sustainable agriculture to ensure human and animal food production with a minimal disturbance to the environment is the exploration of microbe-based symbioses in plants (Marella, 2014). Plants are naturally subjected to drought, salt and cold stress.

Table.1 Plant Growth Promoting Activity of Endophytes

\begin{tabular}{|c|c|c|c|}
\hline Endophyte & Activity & Source & Reference \\
\hline & Plant growth promotion & Halophytes & You et al. (2012) \\
\hline \multicolumn{4}{|l|}{ Fungi } \\
\hline Fungi & Plant growth promotion & $\begin{array}{l}\text { Vitex rotundifolia, Calystegia } \\
\text { soldanella, Lathyrus littoralis, } \\
\text { Polygonum convolvulus, } \\
\text { Oxalis corniculata, Lathyrus } \\
\text { japonica, Ixeris repenes, } \\
\text { Glehnia littoralis and Salsola } \\
\text { komarovi }\end{array}$ & Khan et al. (2012) \\
\hline Fungi & Plant growth promotion & $\begin{array}{l}\text { Rosa rugosa, Camellia } \\
\text { japonica, Delonix regia, } \\
\text { Dianthus caryophyllus and } \\
\text { Rosa hybrid }\end{array}$ & Zhou et al. (2014) \\
\hline $\begin{array}{l}\text { Cladosporium } \\
\text { sphaerospermum }\end{array}$ & Plant growth promotion & Glycine max (L.) Merr. & Hamayun et al. (2009) \\
\hline Bacillus sp. & Plant growth promoting & Sorghum bicolor L. & Luo et al. (2012) \\
\hline Fungi & $\begin{array}{l}\text { Plant growth promotion } \\
\text { [Indole acetic acid (IAA)] }\end{array}$ & Aromatic rice & Syamsia et al. (2015) \\
\hline $\begin{array}{l}\text { Pseudomonas } \\
\text { aeruginosa, P. } \\
\text { putida, P. cepacia } \\
\text { and } P \text {. fluorescens }\end{array}$ & $\begin{array}{l}\text { IAA, hydrogen cyanide } \\
(\mathrm{HCN}) \text {, siderophore and } \\
\text { phosphorous } \\
\text { solubilization }\end{array}$ & Rice crop & $\begin{array}{l}\text { Deshwal and Kumar } \\
\text { (2013) }\end{array}$ \\
\hline Bacillus $\quad s p$. & IAA and siderophore & Avicennia marina $L$. & Janarthin \\
\hline $\begin{array}{l}\text { Sporosarcina } \\
\text { aquimarina and }\end{array}$ & & & Eganathan (2012) \\
\hline Enterobacter $s p$ & & & \\
\hline $\begin{array}{l}\text { Enterobacter } \\
\text { hormaechei }\end{array}$ & IAA & Shorea selanica & Widowati et al. (2013) \\
\hline $\begin{array}{l}\text { Endophytic } \\
\text { diazotrophic } \\
\text { bacteria }\end{array}$ & Auxin, siderophore & Korean rice cultivars & $\underline{\mathrm{Ji}}$ et al. (2014) \\
\hline
\end{tabular}


Table.2 Endophytes Showing Nematicidal Activity

\begin{tabular}{|c|c|c|c|}
\hline Plant species & Endophyte & Nematode species & Reference \\
\hline \multirow[t]{3}{*}{ Cucumber } & Isolated species & Grey mold & An et al. (2005) \\
\hline & $\begin{array}{l}\text { Pseudomonas } \\
\text { fluorescens }\end{array}$ & Meloidogye incognita & Hallmann et al. (1998) \\
\hline & $\begin{array}{l}\text { Fusarium, } \\
\text { Trichoderma, } \\
\text { Chaetomium, } \\
\text { Acremonium, } \\
\text { Paecilomyces and } \\
\text { Phyllosticta }\end{array}$ & M. incognita & Yan et al. (2011) \\
\hline $\begin{array}{l}\text { Tripterygium wilfordii } \\
\text { Hook F. }\end{array}$ & $\begin{array}{l}\text { Cryptosporiopsis cf. } \\
\text { quercina Petr. (f) }\end{array}$ & $\begin{array}{l}\text { Pyricularia oryzae } \\
\text { Cav. }\end{array}$ & Li et al. (2000) \\
\hline Bhendi & $\begin{array}{l}\text { Pseudomonas sp., } \\
\text { Bacillus sp. and } \\
\text { Methylobacterium sp. }\end{array}$ & M. incognita & $\begin{array}{l}\text { Vetrivelkalai et al. } \\
\text { (2010) }\end{array}$ \\
\hline Tomato & $\begin{array}{l}\text { F. oxysporum } \\
P . \text { aeruginosa, } P . \\
\text { fluorescens and } \\
\text { Phyllobacterizrm } \\
\text { rubiacearum }\end{array}$ & $\begin{array}{l}\text { Radopholus similis } \\
\text { Meloidogyne javatzica }\end{array}$ & $\begin{array}{l}\text { Shahasi et al. (2006) } \\
\text { Siddiqui and } \\
\text { Ehtesharnul-Haque } \\
(2000,2001)\end{array}$ \\
\hline Tropical tree & & Nematicidal & Schwarz et al. (2004) \\
\hline
\end{tabular}

Piriformospora indica, which is isolated from the roots of xerophytic woody shrubs such as Prosopis juliflora and Zizyphus nummularia, lacks host specificity and is cosmopolitan in nature. Positive interactions of Pi. indica were established for many important agricultural and horticultural plants, which allowed them to grow under extreme physical and nutrient stress. The fungus promoted plant growth especially in nutrient-deficient soils, conferred tolerance to abiotic (salinity, drought, water, cold, high temperature and heavy metals) and biotic (root and foliar pathogens) stresses, regulated plant growth and development, induced early flowering and enhanced seed production, stimulated the production of active ingredients in medicinal plants and helped in the hardening of micro-propagated or tissue-cultured plants. The interactions of $P i$. indica also tested with the model plants Arabidopsis thaliana and Hordeum vulgare to understand the molecular basis of these beneficial plant-microbe interactions. The current knowledge about the role of $P i$. indica in improving the crop productivity and also in enhancing tolerance of the plant to biotic and abiotic stresses (Johnson et al., 2014).

Bacterial strains such as Arthrobacter sp. and Bacillus sp. were isolated from pepper plant resulted in a significant reduction of upregulation and even downregulation of some stress-inducible genes when compared with gene expression in uninoculated plant (Sziderics et al., 2007). Phoma glomerata and Penicillium sp. associated with cucumber plants significantly increased the plant biomass, related growth parameters, assimilation of essential nutrients such as potassium, calcium, magnesium and reduced the sodium toxicity under sodium chloride and polyethylene glycol-induced salinity and drought stress when compared with control plants. Under stress conditions, the endophyte infection significantly modulated stress through downregulated abscissic acid, 
altered jasmonic acid and elevated salicylic acid contents when compared with control. In conclusion, the two endophytes significantly reprogrammed the growth of host plants during stress conditions (Waqas et al., 2012).

The endophytic fungal symbiosis of Penicillium minioluteum also increased the Daidzein and Genistein contents in the soybean when compared with control plants, under salt stress. Thus, $P$. minioluteum showed the adverse effects of abiotic salinity stress and rescued soybean plant growth by influencing biosynthesis of the plant's hormone and flavonoids (Khan et al., 2012).

In conclusion, nearly 300,000 plant species exist in this world. Every plant harbour one to hundreds of endophytes. Each endophyte, bacterium or fungus, has their own function and protects the plants from various factors. But still the mechanism behind its action on their host plant is not yet clear. Many unsolved problems are present in endophyte research, therefore, many workers are involved in endophyte research to show its potential to solve many problems faced by mankind. India being a tropical country with great variation in biodiversity offer more chances to chase more endophytes that are suitable to produce bioactive compounds.

\section{References}

An, R.P., Ma, Q. 2005. Control of cucumber grey mold by endophytic bacteria. Cucurbit Genetics Cooperative Report, 28-29, 1-6.

Aravind, R., Antony, D., Eapen, S.J., Kumar, A., Ramana, K.V. 2009. Isolation and evaluation of endophytic bacteria against plant parasitic nematodes infesting black pepper (Piper nigrum L.). Indian J. Nematol., 39(2): 211-217.
Arnold, A.E., Engelbrecht, B.M.J. 2007. Fungal endophytes nearly double minimum leaf conductance in seedlings of a neotropical tree species. J. Trop. Ecol., 23: 369-372.

Arnold, A.E., Herre, E.A. 2003. Effects of canopy cover and leaf age on colonization by tropical fungal endophytes: pattern and process in Theobroma cacao (Malvaceae). Mycologia, 95: 388-398.

Azevedo, J.L., Pereira, J.O., Araujo, W.L. 2000. Endophytic microorganisms: a review on insect control and recent advances on tropical plants. Electronic J. Biotechnol., 3(1): 40 65.

Baldani, J.I., Caruso, L., Baldani, V.L.D., Goi, S.R., Döbereiner, J. 1997. Recent advances in BNF with nonlegume plants. Soil Biol. Biochem., 29: 911-922.

Bandara, W.M.M.S., Scncviratnc, G., Kulasooriya, S.A. 2006. Interaction among endophytic bacteria and fungi: effects and potentials. J. Biosci., 31(5): 645-650.

Barka, E.A., Gognies, S., Nowak, J., Audran, J.C., Belarbi, A. 2002. Inhibitory effect of endophyte bacteria on Botrytis cinerea and its influence to promote the grapevine growth. Biol. Control, 24: 135-142.

Bevivino, A., Sarrocco, S., Dalmastri, C., Tabacchioni, C., Cantale, C., Chiarini, L. 1998. Characterization of a free-living maize-rhizosphere population of Burkholderia cepacia: effect of seed treatment on disease suppression and growth promotion of maize. FEMS Microbiol. Ecol., 27: 225-237.

Bhowmik, B., Singh, R.P., Jayaraman, J., Verma, J.P. 2002. Population dynamics of cotton endophytic Pseudomonas, their antagonism and 
protective action against the major pathogens of cotton. Indian Phytopatheol., 55: 124-132.

Bing, L.A., Lewis, L.C. 1993. Occurrence of the entomopathogen Beauveria bassiana (Balsamo) Vuillemin on distribution, host-choice and performance of the hairy chinch bug (Hemiptera: Lygaeidae). J. Economic Entomol., 63: 324-328.

Compant, S., Reiter, B., Sessitsch, A., Nowak, J., Clément, C., Barka, E.A. 2005. Endophytic colonization of Vitis vinifera $\mathrm{L}$. by a plant growthpromoting bacterium, Burkholderia sp. strain PsJN. Appl. Environ. Microbiol., 71: 1685-1693.

Costa, J.M., Loper, J.E. 1994. Characterization of siderophore production by the biological-control agent Enterobactercloacae. Mol. Plant-Microbe Interactions J., 7: 440-448.

Dai, C.C., Yu, B.Y., Li, X. 2008. Screening of endophytic fungi that promote the growth of Euphorbia pekinensis. African J. Biotechnol., 7: 3505-3510.

Daisy, B.H., Strobel, G.A., Castilo, U., Ezra, D, Scars, J., Weaver, D. 2002. Nepthalene, an insect repellent, is produced by Muscodor vitigenus, a novel endophytic fungus. Microbiol., 148: 3737-3741.

Dalal, J., Kulkarni, N. 2013. Antagonistic and plant growth promoting potentials of indigenous endophytic bacteria of soybean (Glycine max (L) Merril). Curr. Res. Microbiol. Biotechnol., 2: 62-69.

Deshwal, V.K., Kumar, P. 2013. Plant growth promoting activity of Pseudomonads in rice crop. Int. J. Curr. Microbiol. Appl. Sci., 2(11): 152-157.

Dingle, J., Mcgee, P.A. 2003. Some endophytic fungi reduce the density of pustules of Puccinia recondita $\mathrm{f}$. sp. tritici in wheat. Mycol. Res., 107: 310-6.

Doley, P., Jha, D.K. 2010. Endophytic fungal assemblages from ethnomedicinal plant Rauwolfia serpentina (L.) Benth. J. Plant Pathol. Microbiol., 40(1): 44-48.

Dutta, D., Puzari, K.C., Gogoi, R., Dutta, P. 2014. Endophytes: exploitation as a tool in plant protection. Brazilian Arch. Biol. Technol., 57(5): 621-629.

Fu, Z.Q., Xia, Z.J., Wu, A.M., Yang, Y.H., Zheng, Q., Gu, B.K. 1999. The mechanism for controlling cotton wilt (Verticillium dahliae) by endophytic bacteria. Jiangsu J. Agri. Sci., 15: 211-215.

Gaiero, J.R., McCall, C.A., Thompson, K.A., Day, N.J., Best, A.S., Dunfield, K.E. 2013. Inside the root microbiome: bacterial root endophytes and plant growth promotion. American J. Bot., 100: 1738-1750.

Gao, F., Dai, C., Liu, X. 2010. Mechanisms of fungal endophytes in plant protection against pathogens. African J. Microbiol. Res., 4(13): 1346-1351.

Gimenez, C., Cabrera, R., Reina, M. Coloma, A. 2007. Fungal endophytes and their role in plant protection. Curr. Organic Chem., 11: 707-720.

Gunatilaka, A.A.L. 2006. Natural products from plant-associated microorganisms: distribution, structural diversity, bioactivity, and implications of their occurrence. $J$. Natural Products, 69: 509-526.

Hallmann, J., Quadt-Hallmann, A., Mahaffee, W.F., Kloepper, J.W. 1997. Bacterial endophytes in agricultural crops. Canadian $J$. Microbiol., 43(10): 895-914.

Hallmann, J., Quadt-Hallmann, A., Rodriguez-Kibana, R., Kloepper, 
J.W. 1998. Interactions between Meloidogyne incognita and endophytic bacteria in cotton and cucumber. Soil Biol. Biochem., 30: 925-937.

Hamayun, M., Khan, S.A., Iqbal, I., Hwang, Y.H., Shin, D.H., Sohn, E.Y., Lee, B.H., Na, C.I., Lee, I.J. 2009. Chrysosporium pseudomerdarium produces gibberellins and promotes plant growth. J. Microbiol., 47: 425430.

Hamayun, M., Khan, S.A., Khan, A.L., Shin, J.H., Lee, I.J. 2010. Exogenous gibberellic acid reprograms soybean to higher growth, and salt stress tolerance. J. Agri. Food Chem., 58: 7226-7232.

Hamayun, M., Khan, S.A., Iqbal, I., Ahmad, B., Lee, I.J. 2010. Isolation of a gibberellin-producing fungus (Penicillium sp. MH7) and growth promotion of crown daisy (Chrysanthemum coronarium). J. Microbiol. Biotechnol., 20: 202-207.

Hardoim, P.R., Van Overbeek, L.S., Van Elsas, J.D. 2008. Properties of bacterial endophytes and their proposed role in plant growth. Trends in Microbiol., 16: 463-471.

Harley, J.L., Smith, S.E. 1983. Mychorrizal Symbiosis. New York: Academic Press, pp. 123-127.

Holland, M.A. 1997. Occam's razor applied to hormonology: are cytokinins produced by plants. Plant Physiol., 115: 865-868.

Igarashi, Y., Iida, T., Sasaki, Y., Saito, N., Yoshida, R., Furumai, T. 2000. Isolation of actinomycetes from live plants and evaluation of antiphytopathogenic activity of their metabolites. Actinomycetologica, 16: 9-13.

Istifadah, N., Mcgee, P.A. 2006. Endophytic Chaetomium globosum reduces development of tan spot in wheat caused by Pyrenophora triticirepentis. Australasian Plant Pathol., 35: 411-418.

Janarthine, S.R.S., Eganathan, P. 2012. Plant growth promoting of endophytic Sporosarcina aquimarina SjAM16103 isolated from the pneumatophores of Avicennia marina L. International J. Microbiol., 1-10.

Jasim, B., Jimtha, John, C., Mathew, J., Radhakrishnan, E.K. 2013. Plant growth promoting potential of endophytic bacteria isolated from Piper nigrum. Plant Growth Regulation, 71: 1-11.

Jha, B., Gonita, I., Hartmann, A. 2012. The roots of halophyte Salicornia brachalata are a source of new halotolerant diazotrophic bacteria with plant growth-promoting potential. Plant and Soil, 356: 265277.

Ji Sang Hye, Gururani Mayank Anand, Chun Se-Chul. 2014. Isolation and characterization of plant growth promoting endophytic diazotrophic bacteria from Korean rice cultivars. Microbiol. Res., 169(1): 83-98.

Johnson, J.M., Alex, T., Oelmüller, R. 2014. Piriformospora indica: the versatile and multifunctional root endophytic fungus for enhanced yield and tolerance to biotic and abiotic stress in crop plants. J. Trop. Agri., 52(2): $103-122$.

Khan, A.L., Hamayun, M., Kang, S.M., Kim, Y.H., Jung, H.Y., Lee, J.H., Lee, I.J. 2012. Endophytic fungal association via gibberellins and indole acetic acid can improve plant growth potential in abiotic stress: an example of Paecilomyces formosus LHL10. BMC Microbiol., 12: 3.

Khan, A.L., Hamayun, M., Ahmad, N., 
Hussain, J., Kang, S., Kim, Y., Adnan, M., Tang, D., Waqas, M., Radhakrishnan, R., Hwang, Y., Lee, I. 2011. Salinity stress resistance offered by endophytic fungal interaction between Penicillium minioluteum LHL09 and Glycine max L. J. Microbiol. Biotechnol., 21(9): 893-902.

Koga, H., Hirai, Y., Kanda, K., Tsukiboshi, T., Uematsu, T. 1997. Successive transmission of resistance to bluegrass webworm to perennial ryegrass and tall fescue plants by artificial inoculation with Acremonium endophytes. Japan Agri. Res., 31: 109-115.

Lee, S., Flores-Encarnacion, M., ContrerasZentella, M., Garcia-Flores, L., Escamilla, J.E., Kennedy, C. 2004. Indole-3-acetic acid biosynthesis is deficient in Gluconacetobacter diazotrophicus strains with mutations in cytochrome $\mathrm{C}$ biogenesis genes. $J$. Bacteriol., 186: 5384-5391.

Li, H., Huang, H., Shao, C., Huang, H., Jiang, J., Zhu, X., Liu, Y., Liu, L., Lu, Y., Li, M., Lin, Y., She, Z. 2011. Cytotoxic norsesquiterpene peroxides from the endophytic fungus Talaromyces flavus isolated from the mangrove plant Sonneratia apetala. J. Natural Products, 74(5): 12301235.

Li, J.Y., Strobel, G.A., Harper, J.K., Lobkovsky, E., Clardy, J. 2000. Cryptocin, a potent tetramic acid antimycotic from the endophytic fungus Cryptosporiopsis quercina. Organic Lett., 2: 767-770.

Lu, H., Zou, W.X., Meng, J.C., Hu, J., Tan, R.X. 2000. New bioactive metabolites produced by Colletotrichum sp., an endophytic fungus in Artemisia annua. Plant Sci., 151: 67-73.

Luo, S., Xu, T., Chen, L., Chen, J., Rao, C.,
Xiao, X., Wan, Y., Zeng, G., Long, F., Liu, C., Liu, Y. 2012. Endophyteassisted promotion of biomass production and metal-uptake of energy crop sweet sorghum by plantgrowth-promoting endophyte Bacillus sp. SLS18. Appl. Microbiol. Biotechnol., 93: 1745-1753.

Malinowski, D.P., Zuo, H., Belesky, D.P., Alloush, G.A. 2004. Evidence for copper binding by extracellular root exudates of tall fescue but not perennial ryegrass infected with Neotyphodium spp. endophytes. Plant and Soil, 267: 1-12.

Marella, S. 2014. Bacterial endophytes in sustainable crop production: applications, recent developments and challenges ahead. Int. J. Life Sci. Res., 2(2): 46-56.

Mei, C., Flinn, B.S. 2010. The use of beneficial microbial endophytes for plant biomass and stress tolerance improvement. Recent Patents on Biotechnol., 4(1): 81-95.

Patterson, C.G, Potter, D.A., Fannin, F.F. 1992. Feeding deterency of alkaloids from endophyte-infected grasses to Japanese beetle grubs. Entomol. Exp. Appl., 61: 285-289.

Pirttila, A., Joensuu, P., Pospiech, H., Jalonen, J., Hohtola, A. 2004. Bud endophytes of Scots pine produce adenine derivatives and other compounds that affect morphology and mitigate browning of callus cultures. Physiol. Plant, 121: 305312.

Rajendran, L., Saravanakumar, D., Raguchander, T., Samiyappan R.2006. Endophytic bacterial induction of defence enzymes against bacterial blight of cotton. Phytopathol. Mediterr, 45: 203-214.

Sapak, Z., Meon, S., Ahmad, Z.A.M, 2008. Effect of endophytic bacteria on 
growth and suppression of Ganoderma infection in oil palm. Int. J. Agri. Biol., 10: 12-132.

Schwarz, M., Koepcke, B., Weber, R.W.S., Sterner, O., Anke, H. 2004.3Hydroxypropionic acid as a nematicidal principle in endophytic fungi. Phytochemistry, 65: 22392245.

Shahasi, A., Dubois, Y., Viljoen, A., Nico, L., Ragama, P., Niere, B. 2006. In vitro antagonism of endophytic Fusarium oxysporum isolates against the burrowing nematode Radopholus similis. Nematol., 8(4): 627-636.

Sheng, X.F., Xia, J.J., Jiang, C.Y., He, L.Y., Qian, M. 2008. Characterization of heavy metal-resistant endophytic bacteria from rape (Brassica napus) roots and their potential in promoting the growth and lead accumulation of rape. Environ. Poll., 156:1164-1170.

Shin, D.S., Park, M.S., Jung, S., Lee, M.S., Lee, K.H., Bae, K.S., Kim, S.B. 2007. Plant growth-promoting potential of endophytic bacteria isolated from roots of coastal sand dune plants. $J$. Microbiol. Biotechnol., 17(8): 13618.

Siddiqui, I.A., Ehteshamul-Haque, S. 2000 a. Use of Pseudomonas aevuginosa for the control of root rot-root knot disease complex in tomato. Nematologia Meditevvanea, 28: 189192.

Siddiqui, I.A., Ehteshamul-Haque, S., Zaki, M.J., Shaukat, S.S., Ghaffar, A. 2001. Contro1 of the chickpea root-knot complex with Pseudomonas aevuginosa and selected pesticides. Int. J. Nematol., 11: 85-91.

Strobel, G.A., Daisy, B.2003. Bioprocessing for microbial endophytes and their natural products. Microbiol. Mol. Biol. Rev., 67: 491-502.

Strobel, G.A., Miller, R.V., Miller, C.,
Condron, M., Teplow, D.B., Hess, W.H. 1999. Cryptocandin, a potent antimycotic from the endophytic fungus Cryptosporiopsis cf. quercina. Microbiol., 145: 1919-1926.

Sturz, A.V., Christie, B.R., Matheson, B.G. 1998. Associations of bacterial endophyte populations from red clover and potato crops with potential for beneficial allelopathy. Canadian J. Microbiol., 44: 162-167.

Syamsiaa, Kuswinantib, T., Syam'unb, E., Masniawatic, A. 2015.The Potency of Endophytic Fungal Isolates Collected from Local Aromatic Rice as Indole Acetic Acid (IAA) Producer. Procedia Food Sci., 3: 96 - 103.

Sziderics, A.H., Rasche, F., Trognitz, F., Sessitsch, A., Wilhelm, E. 2007. Bacterial endophytes contribute to abiotic stress adaptation in pepper plants (Capsicum annuum L.). Can. J. Micobiol., 53: 1195-1202.

Tan, R.X., Zou, W.X. 2001. Endophytes: a rich source of functional metabolites. Nat. Prod. Rep, 18: 448-459.

Tsavkelova, E.A., Cherdyntseva, T.A., Botina, S.G., Netrusov, A.I. 2007. Bacteria associated with orchid roots and microbial production of auxin. Microbiol. Res., 162: 69-76.

Verma, S.C., Ladha, J.K., Tripathi, A.K. 2001. Evaluation of plant growth promoting and colonization ability of endophytic diazotrophs from deep water rice. J. Biotechnol., 91: 127141.

Vetrivelkalai1, P., Sivakumar, M., Jonathan, E.I. 2010. Biocontrol potential of endophytic bacteria on Meloidogyne incognita and its effect on plant growth in Bhendi. J. Biopesticides, 3(2): 452-457.

Wakelin, S., Warren, R., Harvey, P., Ryder, M. 2004. Phosphate solubilization by Penicillium spp. closely associated 
with wheat roots. Bio. Fert. Soils, 40: 36-43.

Waqas, M., Khan, A.L., Kamran, M., Hamayun, M., Kang, S.M., Kim, Y.H., Lee, I.J. 2012. Endophytic Fungi Produce Gibberellins and Indoleacetic Acid and Promotes HostPlant Growth during Stress. Mol., 17: 10754-10773.

Waweru, B., Turoop, L., Kahangi, E., Coyne, D., Dubois, T. 2014. Nonpathogenic Fusarium oxysporum endophytes provide field control of nematodes, improving yield of banana (Musa sp.). Biol. Control, 74: 82-88.

Webber, J. 1981. A natural control of Dutch elm disease. Nature, 292: 449-451.

Widowati, T., Nuriyanah, Sukiman, H. 2013. Potency of Endophyte Bacterium Isolated from Shorea selanica on Producing IAA Hormone and Supporting the Growth of Soybean. Annales Bogorienses, 17(2): 35-41.

Yan, X., Sikora, R.A., Zheng, J.W. 2011. Potential use of cucumber (Cucumis sativus L.) endophytic fungi as seed treatment agents against root-knot nematode Meloidogyne incognita. $J$ Zhejiang Univ. Sci. B, 12(3): 219225.

You, Y.H., Yoon, H., Kang, S.M., Shin, J.H., Choo, Y.S., Lee, I.J., Lee, J.M., Kim, J.G. 2012.Fungal diversity and plant growth promotion of endophytic fungi from six halophytes in Suncheon Bay. J. Microbiol. Biotechnol., 22: 1549-1556.

Zabalgogeazcoa. 2008. Fungal endophytes and their interaction with plant pathogens, Spanish J. Agri. Res., 6 (Special issue):138-146.

Zhang, H.W., Song, Y.C., Tan, R.X. 2006. Biology and chemistry of endophytes. Nat. Pro. Rep., 23: 753-771.

Zhou, Z., Zhang, C., Zhou, W., Li, W., Chu, L., Yan, J., Li, H. 2014. Diversity and plant growth-promoting ability of endophytic fungi from the five flower plant species collected from Yunnan, Southwest China. J. Plant Interactions, 9(1): 585-591.

\section{How to cite this article:}

Rukshana Begum, S., and Tamilselvi, K.S. 2016. Endophytes are Plant Helpers: An Overview. Int.J.Curr.Microbiol.App.Sci.5(4): 424-436. doi: http://dx.doi.org/10.20546/ijcmas.2016.504.050 